\title{
МУЗИЧНІ РЕФЛЕКСІЇ НА ТРАГІЧНІ ПОДІЇ ХХ-ХХІ СТОЛІТЬ У ТВОРЧОСТІ ЄВРОПЕЙСЬКИХ ТА УКРАЇНСЬКИХ КОМПОЗИТОРІВ
}

\author{
Щербакова О. К., Щербаков Ю. В.
}

\section{ВСТУП}

Мистецтво завжди спроможне виконувати функції дзеркала, в якому відображались еволюційні зміни історії соціуму та процеси формування нашої цивілізації. Чимало художніх артефактів, у яких відбилась історія становлення людського суспільства, свідчать про трагічні події, котрі ставали знаковими для певної епохи, та допомагають сформувати цілісну уяву про неї. Війни, стихійні лиха, катастрофи, епідемії супроводжували людство на всіх етапах цивілізаційного процесу. Найчастіше вони негативним чином впливали на поступальний рух людства і формування гармонійної моделі цивілізаційних взаємин між людьми та державами.

Знакові твори світового мистецтва, серед яких пам'ятник античної літератури «Іліада» Гомера, серія гравюр «Жахи війни» Франческо Гойі, кінофільм «Титаник» Джеймса Кемерона, «Воєнний реквієм» Бенджаміна Бріттена, картина «Герніка» Пабло Пікассо, скульптура «Громадяни Кале» Огюста Родена не лише нагадують про наслідки жахливих подій, розширюють горизонти світосприйняття, але й слугують своєрідним запобіжником, застереженням для людей.

Особливо руйнівними наслідками соціальних, політичних, техногенних, кліматичних і екологічних катастроф наповнена історія $\mathrm{XX}$ століття та сучасності. Науково-технічний прогрес, досягнення фундаментальної науки цього періоду часто стають засобом для розробки нових видів озброєння, які ставлять цивілізацію під загрозу виживання. Дві світові війни, в результаті яких загинули десятки мільйонів людей, змінили уявлення про межу трагедійності у реальному житті та про величезну консолідовану відповідальність, яка може й повинна уберегти світ від повторення подібних катастрофічних подій.

Засоби музичної мови, якими володіє композитор, певною мірою дають можливість у художній формі оголити хворобливу конфліктність опозицій: життя - смерть, гармонія - хаос, міг - вічність. Трагічне, як естетична категорія, посідає основне місце у філософії поряд 3 категоріями піднесеного i прекрасного. Тому, на думку авторів, дослідження творчого відгуку європейських і українських композиторів 
на трагічні події XX - початку XXI століття може допомогти розкриттю ролі музичного мистецтва у багатовимірній картині сучасного світу.

Особливі механізми впливу мистецтва на естетичне і психологічне сприйняття навколишнього середовища через органи почуттів, емоції та інструменти інтелектуального пізнання, сформували уявлення про унікальність мистецтва як однієї 3 важливих складових частин загальнолюдської культури. Як прозорливо відзначив Томас Еліот, «вплив твору мистецтва на того, хто насолоджується цим твором, викликає переживання, яке принципово відмінне від будь-якого іншого переживання, не пов'язаного 3 мистецтвом. Такий вплив може бути стимульований або окремою емоцією, або поєднанням декількох...» ${ }^{1}$.

Перші спроби охарактеризувати трагедію і катарсис були зроблені ще в античні часи Аристотелем. У різні епохи чимало знакових фігур філософської та естетичної думки (Ф. Шиллер, Г. Гегель, А. Шопенгауер, С. Кьєргегор, К. Ясперс та інші) працюють над розкриттям значення понять «катарсис» та «трагічне», які наповнюються новим змістом, набувають додаткових характеристик, збагачуються актуальною змістовністю. Новий ракурс бачення проблематики знаходимо у монографії О. Самойленко, яка констатує, що «катарсис формується у зв'язку 3 потребою відновлення цілісності свідомості, єдності фідеїстичного, когнітивного й «розуміючого» іiі рівнів, прямувань. Одночасно слушними залишаються визначення катарсису як «очищення» вірою, знанням і розумінням у їх відособленості, тому що в кожного 3 цих «очищень» свій історичний та психологічний шлях» ${ }^{2}$.

Музичне мистецтво здатне 3 великою мірою конкретизації відобразити трагічні події, використовуючи зовсім іншій інструментарій виразових засобів, ніж література, живопис, скульптура та інші види мистецтва. Творчість європейських та українських композиторів XX-XXI століть доводить можливості музики оперативно та ефективно реагувати на руйнівні виклики нашої епохи. Дієва сила музики впливає на осмислення та вирішення проблем онтологічного рівню та виконує високі завдання катартичного оновлення людини та суспільства.

\section{1. Відлуння трагічних подій XX-XXI століть у творчості свропейських композиторів}

Твори багатьох європейських композиторів XX-XXI століть свідчать про високий ступінь активного творчого реагування митців на трагічні та катастрофічні обставини людського буття. Однією 3 найбільших трагедій XX століття стала розпочата 1 серпня 1914 року Перша світова

\footnotetext{
${ }^{1}$ Элиот Т.С. Традиции и индивидуальный талант. Зарубежная эстетика и теория литературы XIX-XX вв. Трактаты, статьи, эссе. Изд-во Московского ун-та. 1987. С. 173.

${ }^{2}$ Самойленко О.І. Психологія мистецтва: сучасні музикознавчі проєкції : монографія. Одеса : Вид. дім «Гельветика», 2020. С. 129. 
війна. Уперше в історії було застосовано у боях хімічну зброю, що призвело до тяжких людських втрат. Близько 10 мільйонів загиблих, більш ніж 12 мільйонів поранених - такий підсумок цієї жахливої епопеї. Музиканти, як і інші діячі культури країн Європи (безпосередньо чи опосередковано), також ставали учасниками цих подій.

Потужним відгуком на конкретні події Першої світової війни став цикл італійського майстра Альфредо Казелли "Сторінки війни» ("Pagini di Guerra") «Чотири музичні фільми» для фортепіано у 4 руки op. 25, створений у 1915 році. Часто виникає питання: чому композитор додав до основної назви уточнення «Чотири музичні фільми»? Це можемо пояснити тим, що після ознайомлення з воєнною кінохронікою композитор був вражений побаченим і вирішив створити музичний аналог конкретним кінокадрам війни у різних країнах, що підкреслює історично-соціальне значення цього творчого авторського проєкту.

Цикл А. Казелли «Сторінки війни» ${ }^{3}$ має конкретну програму, але його не можна віднести до суто ілюстративної музики, тому що музичне висловлювання наповнено експресивними почуттями персонального авторського погляду на події. Специфіка прийомів фільмової музики значно підсилює роль реалістичного фактора, що яскраво відображується у п'єсах циклу, пов'язаних зі звукозображальністю. Загострення дисонантного звучання, нерегулярні зміни метра на фоні нестримного механістичного руху - усе це допомогло Казелли у першій п’єсі циклу «В Бельгї̈: пересування тяжкої німецької артилерї̈» відобразити динамічну картину пересування військової техніки близько до кінозйомки «крупним планом». Композитор приділяе велику увагу необхідним для виконавців твору ремаркам, які виявляють внутрішню бездуховність, антиемоційність механістичних образів. У музиці ми «бачимо» реалістичність неочікуваного зіткнення машини з перепоною і iii зворотний маневр. Віддалення військової колони чітко «бачиться» в драматургічній складовій частині п’єси та буквально прочитується в цепі авторських ремарок: stridente - confusamente - perdendosi - lontano (пронизливо - у замішанні - зникаючи - віддалено) та динаміці $p p, p p p$, ррpp.

Після щільного звукового напору першої п’єси друга п’єса «У Франції: біля руїн Реймського собору» різко змінює емоційний стан слухача. Це молитовний роздум людини біля зруйнованої святині... Хоральне низхідне прямування двох квінт 3 інтервалом у секунду (партія Secondo), приєднання до цієї поступі низхідних акордів (партія Primo) та застосування піаністами (за указівкою автора) «на кожній чверті педалі у всій п’єсі зі значною таємничістю» створюють доволі

\footnotetext{
${ }^{3}$ Вперше в Україні цикл А. Казелли «Сторінки війни» виконав фортепіанний дует О. Щербакової та Ю. Щербакова 21 лютого 2000 року у Золотому залі літературного музею м. Одеси.
} 
похмуру темброво-колористичну картину. Невеличка за розміром п'єса наповнена тонкими нюансами імпресіоністичної звукової палітри, яка нагадує множинність кольорових відтінків Руанського собору в серії картин Клода Моне.

Третій «фільм» циклу «У Росії: атака козацької кавалерії» вражає широкою амплітудою розвитку динаміки руху, яка від основного темпу (Allegro molto vivace) спрямована на прискорення до кінця композиції. Ефект нагнітання драматизму здійснюється шляхом безперервного наближення звукової маси, що вербально відображено авторськими ремарками у нотному тексті: «віддалено, як би невловимо», «наближаючись», «несамовито». Агресивний ритм атаки вершників (безперервний рух восьмих на staccatissimo sempre) мовби передбачає відгук сердцево-нервової системи слухача, особливо з урахуванням нагнітання напруженості у разі постійного прискорення руху (stringendo progressivamente, stringendo sempre). Несамовитість атаки підкріплена жорстко акцентованими акордами (marcatissimo) в партії Primo, а потім зловісно-погрожуючим звучанням басів в партії Secondo. Різким, як постріл, акордом secco, відділеному паузою від безперервного попереднього руху, автор раптово зупиняє цей рух та закінчує п'єсу, залишаючи відчуття афектованої збудженості.

Цикл «Сторінки війни» завершує п’єса «B Ельзасі: дерев'яні хрести...». Могили загиблих у війні - це скорботний підсумок будь-яких воєнних баталій. Траурний та жалісний характер оціпенілих інтонацій та тихе примарне звучання на лівій педалі малюють картину застиглого цвинтаря та сиротливих могил.

У циклі Альфредо Казелли кожен 3 чотирьох «музичних фільмів» розповідає окрему історію. В кожній частині спостерігаємо експансію одного настрою, конкретизацію одного зображення, розробку одного тематичного матеріалу. П'єси розташовані за принципом контрастної зміни картин битви i скорботно-ліричних образів, які органічно вплітаються в розгортання драматургії, як нагадування слухачеві про наслідки воєнних конфліктів. Завдяки такому поєднанню брутального 3 душевним сумом та проникливою емоційністю, драматизм твору проявляється у ще більш загостреній формі.

Альфредо Казелла, в душі якого події воєнних років відгукнулись гострим болем, продовжив свою роботу над циклом в оркестровому варіанті. У 1918 році композитор представив новий варіант, який доповнив п’ятою п’єсою під назвою «На Адріатиці: Італійські броненосиі у походi». Таким чином, твір отримав нове життя, збагачене колористичними можливостями, які може надати масштабне оркестрове звучання. 
Враження від Першої світової війни та особисті душевні потрясіння Казелла також відобразив у "Героӥчній елегії пам'яті солдата, який загинув на війні» ор. 29 для великого оркестру. Твір експресіоністичнопсихологічного спрямування втілює глибокі роздуми творця над сенсом людського буття. Контрастна мальовничість, наповнена звучанням складних гармонічних комплексів (інтенсивність яких доходить до жорсткості звучання), та несамовитий характер динамічної амплітуди підкреслюють трагедійність авторського художнього задуму.

Для французького композитора Моріса Равеля, як і для багатьох музикантів, Перша світова війна стала часом тяжких іспитів. У листі до С. Годебського він пише: «Я більш не в силах виносити цей жорстокий, безперервний кошмар. Я або збожеволію, або стану одержимим нав'язливою ідеєю» ${ }^{4}$. Равель добровольцем пішов до армії, стійко переносив тяготи служби, але через два роки у прифронтовій зоні обморозився і був відправлений у тил. Не випадково, що сюїта «Гробниця Куперена» для фортепіано (1917) стала свого роду меморіалом його друзям, загиблим на війні. Можна уявити, яким сумом був сповнений автор, коли вирішив присвятити всі п’єси твору тим, кого він нещодавно бачив живими і кого забрала війна. Такий авторський задум приніс додаткову семантичну наповненість циклу. Кожна 3 шести п’єс має присвяту: «Прелюдія» - Жаку Шарло (другу композитора, який робив перекладення його творів), «Фуга» - Жану Круппі (мати якого була приятелькою Равеля), «Форлана» - Габрієлю Делю (знайомому художнику), «Ригодон» - братам Пьєру і Паскалю Годен (сім'я котрих усе життя дружила 3 Равелем), «Менует» - Жану Дрейфусу (синові «військової хресної» Равеля), «Токата»-Жозефу де Марліафу. Вперше сюїту виконала у 1919 році Маргарита Лонг, вдова Жозефа де Марліафа, якому й присвячена остання п’єса.

Без сумніву, бойові дії також вплинули на творчість Клода Дебюссі, який писав: «...Зараз майже неможливо працювати... Існування поблизу від війни настільки хворобливе для мене, що не можу не думати про це...» ${ }^{5}$. Але композитор, незважаючи на депресію, працював та написав у воєнний період під враженням від драматичних подій твори: «Мелодія сліз», «Різдво дітей, які залишились без даху над головою», «Героїчна колискова», «В білому $і$ чорному».

Можемо припустити, що ідея присвятити п'єси 3 «Гробнищі Куперена» загиблим була використана Морісом Равелем за прикладом Клода Дебюссі, який у 1915 році торкається жахливих реалій Першої світової війни у сюїті для двоклавірного дуету «В білому $\boldsymbol{i}$ чорному». Музика твору насичена інтонаціями тривоги, драматизму, контрастними змінами.

\footnotetext{
${ }^{4}$ Равель в зеркале своих писем / сост. Морис Жерар и Рене Шалю. Ленинград : Музыка, 1988. C. 85 .

${ }^{5}$ Claude Debussy. Correspondance (1882-1918). Gallimard, 2005. P. 1844.
} 
Дуже виразною $є$ символіка воєнного змісту, яка закладена в інтонаційній зображувальності, фанфарності, сигнальності, глухих барабанних ударах, мелодійних елементах «Марсел'єзи». У сюїті Дебюссі всі три частини несуть на собі трагічний відбиток тих подій. Задеклароване у заголовку протиставлення контрастної дихотомічної кольорової опозиції (біле - чорне) налаштовує виконавців та слухачів на психологічне сприйняття цієї музики як боротьби світлого та темного, добра i зла, любові та ненависті. Емоційний центр сюїти - друга частина - має присвяту «Лейтенанту Жаку Шарло, вбитому ворогом у 1915 році, 3 травня» ${ }^{6}$. Також як епіграф композитор додав рядки 3 «Балади проти ворогів Франції» поета Середньовіччя Франсуа Війона. Високий ступінь програмної вербальної інформації, сконцентрованої у художньому задумі композитора, що поєднує програму-передмову 3 програмою-поезією, дає можливість слухачам краще зрозуміти образнотрагічну спрямованість авторського задуму. Не менш складні завдання стоять i перед дуетом виконавців, які повинні перетворити композиторський текст на власне висловлювання, наповнене експресивним та драматичним характером подання музичного матеріалу.

До теми поминання загиблих під час Першої світової війни звернулись також англійські композитори Джон Герберт Фоулдс (John Foulds) («Всесвітній реквієм», 1919-1921рр.) та Едуард Уільям Елгар. На Е. Елгара жахіття війни справили таке враження, що він призупинив на якийсь час свою творчу діяльність. У 1915 році з'являється кантата «Дyx Англії», третя частина якої має назву «Полеглим» і пов'язана 3 однойменним віршем англійського поета Лоуренса Біньона. Цей вірш став символом пам'яті жертвам війни, адже його окремі строфи викарбувані на численних меморіальних дошках. Згодом Е. Елгар знову звернувся до подій війни, написавши «Меморіальну мелодію для Корильона» для сопрано, тенора, хору та оркестру (ор. 80, 1923) спеціально до відкриття корильону на Воєнному меморіалі в Лафборо.

Говорячи про музику як трагічний щоденник історії XX-XXI століть, не можна обійти увагою творчість видатного митця сучасності польського композитора Кшиштофа Пендерецького. На різних етапах творчого шляху він зміг проявити себе і як зухвалий новатор, і як послідовник багатовікових традицій. У стильовій палітрі майстра ніжна лірика існує поруч із грандіозними пророцтвами вселенського масштабу. Чимало жахливих подій сьогодення (серед яких атомний вибух у Хіросімі) поранили вразливу душу композитора, який музикою лікував ii, та душі багатьох людей. Атомне бомбардування японських міст Хіросіми та Нагасакі у 1945 році стало першим страхітливим свідоцтвом

\footnotetext{
6 Жак Шарло був двоюрідним братом Жана Дюрана, видавця творів та близького друга К. Дебюссі. 
руйнівної сили ядерної зброї, призвело до величезної кількості жертв та поставило перед людством гамлетівське питання: «Бути, чи не бути?». Твір «Плач по жсертвах Хіросіми» написаний для 52 струнних інструментів, які за допомогою нестандартних технологічних прийомів звуковидобування створюють неочікувані сонористичні ефекти оркестрового звучання. Слід відзначити, що засобами авангардистських прийомів композитор, який прагнув до конструктивно нових художніх ефектів, зміг передати 3 великою силою почуття жаху, скорботи та страждання сотень тисяч постраждалих. Після трансляції твору крупними радіостанціями до композитора прийшла всесвітня відомість, а його партитура до цього часу є експонатом музею міста Хіросіми.

До церемонії відкриття в 1967 році меморіалу пам'яті замучених в Освенцимі Кшиштоф Пендерецький написав ораторію “Dies irae”, де використав тексти першого письма апостола Павла до Коринфян, поезію сучасників - П. Валері, Т. Ружевича, Л. Арагона, В. Броневського. Спектр музичних засобів, застосованих майстром, сконцентрований на посиленні експресивного звучання та зумовлений моделюванням загальної концепції твору для втілення тих афектів і емоцій, що відповідають рівню людської реакції на найстрашніші події в історії людства.

Протягом чверті століття (1980-2005) Пендерецький працював над вокально-симфонічним твором «Польський реквієм». Цей епічний музичний монумент $є$ драматичним роздумом творця над історією Польщі та трагічними подіями в житті поляків у XX столітті. Структура твору відповідає принципам побудови традиційного католицького реквієму, але його масштаби передбачають не літургійну, а концертну форму виконання. Для втілення своїх ідей композитор залучає розширений склад симфонічного оркестру, до якого вводить групу ударних 38 виконавців, сотню хористів та солістів-співаків. Єдність автора 3 рідною країною та зі своїм народом виявляється у безпосередньому зв'язку деяких частин Реквієму з видатними діячами Польщі і з конкретними подіями польської історії.

Хронологія створення окремих частин «Польського реквієму» допомагає краще усвідомити архітектоніку побудови цього музичного храму. "Lacrimosa" написана у 1980 році, у 10 -ту річницю розстрілу повсталих докерів Гданська, присвячена лідеру «Солідарності» Леху Валенсі. "Agnus Dei" (1981) присвячена кардиналу Стефану Вишинському, а "Recordare Jesu pie" - беатифікації священника Максіміліано Кольбе, який у 1941 році добровільно пішов на смертну кару замість іншого в'язня у Освенцимі. До сорокової річниці Варшавського повстання 1944 року була написана "Dies irae" (1984). Перша редакція «Польського реквієму» виконана під орудою Мстислава Растроповича в 
Штутгарті (1984), а в 1993 році композитор, знов повертаючись до складної історичної теми, додає “Sanctus". «Польський реквієм» знайшов свій остаточний вигляд лише у 2005 році, коли Пендерецький створив останню частину монументального циклу - «Чакону для струнного оркестру», присвячену Папі Івану Павло II. В остаточному вигляді твір складається із 17 частин.

Безумовно, що онтологічна глибина та сила художніх рішень «Польського реквієму» свідчать про загальнолюдську спрямованість авторської волі. Бути, чи не бути нашій цивілізації? Бути, чи не бути гармонії людини і природи? Бути, чи не бути перемозі добра над злом? Відповісти на ці питання намагався своєю творчістю та життям Кшиштоф Пендерецький.

Світ здригнувся, коли в травні 1986 році дізнався про найбільшу техногенну катастрофу в історії людства - аварію на Чорнобильській AEC в Україні, наслідки якої відчуваються і сьогодні. Сотні тисяч людей прямо чи опосередковано постраждали, екологія багатьох країн зазнала значної шкоди. Враження від цього лиха стали приводом для музичних рефлексій європейських композиторів, чимало з яких спрямували творчу енергію на катартичне осмислення жахливого інциденту.

Литовський композитор Вітаутас Баркаускас (Vytautas Barkauskas) про Чорнобильську катастрофу казав: «Я сприйняв цю трагедію дуже

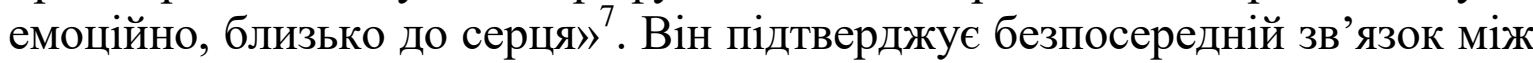
силою власного потрясіння від цих неординарних подій та великою емоціональною виразністю музики своєї Симфонії № 5. Цю симфонію Баркаускас сприймав навіть ширше за поняття «музичний програмний твір», визначаючи його соціально-культурне значення ближче до історичного документа. В драматургію 5-частинного твору закладено широкий спектр схвильованих авторських емоцій (передчуття небезпеки, нервову напруженість, панічне бажання уникнути реальної присутності в трагічній ситуації та інше). Вражає творча ідея композитора в кульмінації симфонії алеаторично поєднати всі теми, коли практично кожен інструмент грає свою тему. Це звукове «місиво», в якому навіть на фортепіано виконується банальний «ганон», створює відчуття повного Хаосу. Драматургічна концепція твору концентрується у Фіналі симфонії, де емоційна пригніченість трансформується у духовне катартичне просвітлення. Як зазначає сам композитор: «Якщо ти не в змозі фізично урятуватися, порятуйся хоча би духовно, усередині самого себе» ${ }^{8}$.

В авторському проєкті естонського композитора Елгіма Страуме (Elgim Straume) «Концерт Че + Че» (“Concerto Che + Che") для двох

\footnotetext{
${ }^{7}$ Гроцкий Д. о творческом методе, политике и Пятой симфонии (беседа Д. Гроцкого с классиком литовской музыки В. Баркаускасом). Ученые записки РАМ им. Гнесиных. 2013, № 1 (4). С. 72.

${ }^{8}$ Гроцкий Д. о творческом методе, политике и Пятой симфонии (беседа Д. Гроцкого с классиком литовской музыки В. Баркаускасом). Ученые записки РАМ им. Гнесиныхх. 2013, № 1 (4). С. 78. 
фортепіано, саксофона і струнного оркестру сучасними виражальними засобами відображена емоційна позиція до двох, не співставних за наслідками трагічних подій, які відбулись у 1986 році на далекій відстані - аварія американського космічного корабля «Челленджер» (загинуло 7 членів екіпажу) та жахлива Чорнобильська катастрофа в Україні. В основі концерту з двох частин - контраст бурної енергії, відображений на рівні агресивного ритмічного напруження та застиглої непорушності. Поява на тлі звукового хаосу мотивів наївних дитячих пісень, з їх спрямованістю на відчуття просвітлення та радощів, вказує дорогу спасіння як альтернативу погроз реальності. Виконання твору, безсумнівно, передбачає володіння учасниками ансамблю арсеналом різноманітних емоційних станів, пов'язаних 3 трагічною програмною складовою частиною композиції. Презентація цього опусу відбулася на Бієнналє сучасної музики у Загребі у 1989 році під орудою литовського диригента Паулюса Сондецкіса.

Напевно, можна казати, що скорботний людський та композиторський досвід, який Елгім Страуме одержав під час створення музичної інтерпретації драматично-схвильованих сторінок у «Конщерті Че + Че», був поширений на музику «Пам'яті жертв катастрофи порома Естонія» ("In memoriam of Ferryboat Estonia") для флейти, віолончелі та клавесину. Пором «Естонія» у 1994 році знаходився на шляху 3 Таллінна до Стокгольма, на його борту було 803 пасажири та 186 членів екіпажу. Внаслідок шторму пором затонув, врятувати вдалося тільки 138 осіб. Ця кораблетроща призвела до найбільшої кількості жертв на Балтійському морі. Як громадянин і як людина Страуме відгукнувся на скорботну подію особистими музичними рефлексіями, в яких віддзеркалились почуття багатьох людей. У 1997 році в Хельсінкі був зроблений запис твору на CD «Пастораль комп'ютеризованого світу».

Фінський композитор Яакко Мянтюярві (Jaakho Mantyjarvi) осмислив цю аварію крізь призму роздумів про людські долі, буття яких миттєво зупинилось у разі неспроможності протистояти руйнівній силі стихії, що втілено у творі «Пісня спустошеного моря" ("Canticum calamitatis Maritimae", 1997).

Музично-чуттєвою реакцією на кораблетрощу порома «Естонія» став також твір естонського композитора Вельо Торміса (Veljo Tormis) «Закляття итормового моря» ("Incantatio maris aestuosi”, 1996), який сконцентрував емоційні сплески почуттів багатьох сучасників. Поєднання релігійно-стриманого музичного висловлювання з введенням звукозображальних елементів, що імітують шипіння морських хвиль, гул двигуна корабля, свистіння вітру, створюють містично-філософську музичну картину. Громадсько-свідоме мислення та потяг до ствердження Краси навколишнього світу живило талант митця та 
спонукало до пошуків творчого шляху в конкретній трагічній тематиці. Таким чином, у 1958 році з'явились кантата «Biŭнa в Maxmpi» (переосмислення подій на півночі Естонії у 1858 році) та «Спогад часів чуми» (1973).

Наведений матеріал не вичерпує повністю тему дослідження, але свідчить про велику концептуальну різноманітність творчих підходів європейських композиторів до втілення гуманістичних та загальнолюдських цінностей у творах, що виникли як музична рефлексія на трагічні події XX-XXI століть.

\section{2. Трагічні імпульси у творчості українських композиторів}

Чимало трагічних подій стали для багатьох українських композиторів XX-XXI століть приводом для музичного осмислення онтологічної проблематики. Можемо спостерігати, що первинний поштовх до творчого висловлювання у українських та європейських композиторів здебільшого співпадає. Перш за все це стосується таких глобальних катастроф, як Друга світова війна та Чорнобильська аварія, що принесли жахливі наслідки для людства. Спільні загальнолюдські цінності та етичні пріоритети об'єднують митців з різних країн.

Органічно поєднались композиторська майстерність та громадський пафос Левка Колодуба у творах симфонічного жанру. Узагальненим музичним образом трагічних сторінок історії України можемо вважати Симфонію № 4 «Пам’яті жертв Чорнобильської трагедї̈» (1986) та Симфонію № 5 «Pro memoria» (Пам’яті жертв страшних лихоліть в Україні) (1990). Симфонія № 4 - це безпосередня рефлексія на Чорнобильську катастрофу, про жахливі наслідки якої вже йшлося в цій статті. Душевний біль та сумні емоції митця знайшли свій вихід у музиці симфонії. Завдяки майстерному володінню виразовими прийомами, які відкривають нові можливості у використанні різних інструментальних груп в оркестрі, композитор зміг наділити цей драматичний твір як психологічним, так і звукозображальним складниками. Дуже важливим засобом розкриття змісту філософських роздумів автора про страшну подію української історії є використання народного мелосу, пов'язаного 3 думами, плачами, церковною традицією заупокійної служби. Сплетіння ліричного вираження, пульсуючого ритму та тембральнопронизливого характеру оркестрового звучання, сповненого відчуттям небезпеки, відтворено у рамках доволі лаконічної концепції одночастинної симфонії. Наскрізний розвиток матеріалу формує у слухача відчуття безпосереднього учасника подій у їх часовому розгортанні.

Симфонія № 5 “Pro memoria” презентує нові риси Левка Колодуба, композитора, який вміє вирішувати глибоко філософські питання у музичній творчості. Важливо, що твір має безпосередній зв'язок 3 
біографією композитора, чий батько був репресований у 1938 році. Його пам'яті та всім невинно замученим у ці страшні роки присвячений цей триптих. Програмні назви кожної 3 частин симфонії («Терор», «Пам'ять», «Катарсис») розкривають внутрішню драматургічну символіку твору. Значну роль у накресленій драматичній лінії грає темброва палітра оркестрової партитури, в якій композитор застосував збільшений склад духових та ударних інструментів, активно використав звучання арфи та челести. Конкретне, образне значення у Симфонії № 5 набуває ефект дзвонів, що символізує духовну єдність народу під час біди. Авторські вказівки у партитурі другої частини симфонії про те, що «у цифрах 43-45 акорди є звукорядами «індивідуальностей» дзвонів К.К. Сараджева» свідчать, що композитор брав до уваги досвід відомого дослідника дзвонів та С. Рахманінова, в творах якого дзвони та «дзвонність» набули значення вагомих емоційно-образних узагальнень.

Музика Симфонії № 5 поєднала відображення жахливих епізодів, де експресія симфонічного вислову вражає своєю жорстокою потужністю, 3 напрочуд світлою мелодійною пісенністю, проникаючою в музичну тканину твору 3 темою Києво-Печерського розспіву, що символізує прямування до духовного очищення у третій частині («Катарсис»). Драматургія симфонії та іï структурна побудова відображають прагнення Левка Колодуба до катартичного переосмислення питань, пов'язаних 3 тяжкими сторінками історії, щоб віднайти віру у можливість відродження.

Досліджуючи творчий доробок Свгена Станковича, можемо звернути увагу на потяг композитора до інтерпретації інформаційно значущих трагічних фактів української історії, що ставлять перед слухачем гострі філософські питання щодо розуміння ваги духовних цінностей у досить непростих процесах, які відбуваються у XX-XXI століттях. Можемо згадати про громадську діяльність митця (він багаторічний керівник Національної спілки композиторів України, один 3 ініціаторів фестивального руху в державі), яка $\epsilon$ важливим складником творчого модусу його композиторської діяльності. Це $\epsilon$ свідченням того, що митець до своєї творчості відноситься як до відповідальної соціокультурної місії.

Дослідники творчості композитора $Є$. Зінкевич та Ю. Чекан серед притаманних його музиці рис відзначають орієнтацію композиторської уваги на драматичний симфонізм. У цьому напрямі він продовжує традиції, які закріплені творчістю Л. Ван Бетховена, П. Чайковського, Г. Малера, Д. Шостаковича. Як зазначав митець, його хвилюють величезні трагічні виверження в музиці Дмитра Шостаковича ${ }^{9}$ 3 великою емоційною силою розкривається почуття трагічності у творах

\footnotetext{
9 Зинькевич Е.С. О настоящем, о былом размышляет Евгений Станкович с Еленой Зинькевич. Нежин : ЧП Лысенко М.М., 2012. С. 129.
} 
Євгена Станковича. «Каддии-реквієм» для читця, тенора, баса, хору й оркестру на слова Дмитра Павличка було створено у 50-ту річницю страшної трагедії у Бабиному Яру, що вразила цивілізований світ жахливою жорстокістю. Мабуть, визначальним елементом посилення значущості психологічно-драматичного розвитку твору стає скорботний характер процесії у поєднанні з експресією соло флейт та скрипок. Емоційна щирість авторського висловлювання у реквіємі підіймає градус сприйняття цих подій до візуально-зображальної конкретики, не зменшуючи ролі сильнодіючого музичного складника трагедійного характеру.

Композитор послідовно та у різних жанрових формах прагне подолати потрясіння від Чорнобильської трагедії. У 1991 році до їі 5-ої річниці Станкович написав «Чорну Елегію» для хору та оркестру на вірші Павла Мовчана. Через рік створює фортепіанне тріо «Музика рудого лісу». В епіграфі нотної партитури тріо автор написав: «Від жахливої радіації після Чорнобильської трагедії ліс навколо став рудим». На наше переконання, ці слова слід враховувати не тільки виконавцям для створення концептуального простору інтерпретації, але й доцільно оприлюднювати для слухачів під час концертної презентації. Композитор розгортає перед слухачем страшну картину сучасності за допомогою музичної образності, яка занурює у світ статики (зупинка в часі), застиглості (мовби фіксування у кадрі моменту зупинки життя), омертвіння (безчуттєвість та безпорадність перед техногенною катастрофою), та максимального вираження експресивності у середній частині тріо. Своєрідний триптих, присвячений Чорнобильській трагедії, композитор завершив у 1993 році твором «Що сталося у тиші після відлуння...” для скрипки, віолончелі, флейти, кларнета, фортепіано, вібрафона, тарілок і трикутника. Використовуючи сонорні інструментальні можливості у поєднанні з різними техніками сучасного композиторського письма, експериментами з музичним звуковим полем, Євген Станкович реалізує свій індивідуальний задум, порушуючи складні питання сьогодення.

У «Панахиді за померлими з голоду 1932-1933 років» (1992) для оркестру та хору Євген Станкович зумів вміло поєднати канонічні тексти (церковно-уставного поминального чину) із сучасною поезією Дмитра Павличка. Згідно з творчим задумом композитора, у творі закріплено поєднання церковних співів («Амінь», «Упокой Боже», «Святий Боже», «Алілуя») 3 українськими народнопісенними інтонаціями. Особливу ліричну експресію надає композиторська ідея заміщення текстів священника звучанням оркестру або скрипки соло. Інструментальний замінник конкретно-вербального тексту суттєво посилює душевний складник твору. Суворість канонічних сторінок Панахиди, єднаючись 3 емоційною проникливістю національно забарвлених інтонацій музичної 
мови, створює неповторну атмосферу. Можемо відзначити інтерес до виконання «Панахиди» у Великобританії, Ізраїлі, Нідерландах, Польщі, Чехії та інших країнах.

За кількістю жертв та масштабами руйнівних наслідків Друга світова війна не має аналогів в історії людства. Десятки мільйонів загиблих, вщент зруйновані міста, сотні мільйонів тілесно та психічно травмованих... Пережити та перебороти цей жах людству допомагає музичне мистецтво.

У творчості композиторів України (деякі з них були безпосередніми учасниками бойових дій) трагічна тема Другої світової війни ставала емоційно-психологічним відгуком на історичні події. Про стійкість людини під час складних випробувань розповідає концерт-сюїта для фортепіано з оркестром «Партизанські картини» Андрія Штогаренка. У шести частинах твору виявляється тяжіння до програмності та яскрава характерність музичної мови. Образні та темпові контрасти зумовлені бажанням автора привернути увагу слухачів до протилежних полюсів емоційно-експресивного враження від цих подій. Відтворення бойових епізодів («Раптовий удар») чергується із скорботно-ліричними сповідальними частинами («Лист матері», «Скорбота матері за вбитим сином»), є також оптимістичний епізод «На привалі». Для створення побутового семантичного колориту використовуються інтонації українських кобзарських дум, плачів та величальних пісень.

Серед авторів, які відобразили воєнну тематику, чимало представників одеської композиторської школи, творчість яких досліджувала Р. Розенберг ${ }^{10}$. Юрій Знатоков на собі відчув трагічні наслідки війни, був поранений та нагороджений бойовим орденом. Симфонічні поеми «Роздуми на Мамаєвому кургані" та «Біля Пискаревського меморіалу" несуть слухачам контрастні почуття, пов'язані із семантикою урочистої тиші, ілюстративно-дієвими епізодами, які змальовують враження від бою, та траурно-скорботними інтонаціями. Близькими до цих творів за образним задумом можна назвати вокально-симфонічну композицію Ігоря Ассєва «Героям, полеглим у боях за Вітчизну» на слова І. Радченко та вокальний цикл "Це не повинно повторитися" на вірші загиблого у концтаборі Заксенхаузен А. Пархоменка. Яскравою прикметою музичного мислення автора $\epsilon$ саме виразність мотивів меморіального вшанування пам'яті загиблих на війні. Вже більш ніж півсторіччя звучить на меморіальній Алеї Слави у місті Одеса «Реквієм пам'яті невідомого матроса» I. Асєєва. Багато туристів зі всього світу відвідують цей меморіал, де музика викликає почуття глибокого співпереживання трагічним подіям та вшанування полеглих.

\footnotetext{
${ }^{10}$ Розенберг Р. Одесская композиторская школа: к 100-летию основания и к 75-летию Одесской организации НСКУ : монография. Одесса : Астропринт, 2013. 328 с.
} 
Звертаючись до відображення трагічної тематики у творчості українських композиторів, можемо згадати оригінальну концепцію хорової сюїти «Пам'ять про війну» (1984) Тамари СидоренкоМалюкової. Ідейно-образний зміст твору визначає універсальні риси відчуття трагічного з точки зору спільних почуттів для різних народів та часів. Поряд 3 переживаннями, пов'язаними 3 війною у своїй країні, композиторка присвячує третю частину сюїти гірким настроям, викликаним атомною трагедією у японському місті Хіросіма.

Яскравим прикладом глибокого втілення трагіко-драматичної концепції є “Largo lamentoso" Богдани Фільц. Твір для двоклавірного дуету став відгуком на наймасштабнішу у світі катастрофу на авіаційному шоу. Під час демонстраційного польоту 27 липня 2002 року літак впав на глядачів на Скнилівському літовищі під Львовом. Загинуло 77 осіб, більш 350 було травмовано... Композиторка повною мірою відчула страшну катастрофу та іï тяжкі наслідки, тому що перебувала у той час у Львові. Щоб довести до слухача програмну ідею, вона поряд 3 назвою "Largo lamentoso" надає уточнення - «під враженням Скнилівської трагедії». Ця ремарка не тільки конкретизує сумну сторінку історії нашої країни, але й несе певну емоційну інформацію про особисті почуття автора, які були поєднані з горем багатьох людей. Вважаємо обгрунтованими спостереження М. Ластовецького щодо впливу скорботних сторінок дитинства Богдани Фільц на реалізацію творчого задуму ${ }^{11}$.

Психологічно-філософський зміст твору розкривається вже у його назві, де поєднання термінів Largo та Lamentoso сильніше акцентує поле внутрішньої семантики. Симптоматично, що Lamento (з італійської жалібно) передбачає музику жалібного, скорботного, тужливого настрою. Таким чином, комплекс $з$ двох музичних термінів, фіксуючи молитовно-плачовий імпульс, відкриває у назві складники концепції Богдани Фільц та постає фундаментом для подальшого асоціативнохудожнього виконавського плану.

Інтерпретатори цього програмного твору стикаються зі складним емоційно-образним завданням, яке передбачає переживання конкретної історичної події та відгук на неї у розмаїтті музичних настроїв, рухів, тембрів, духовної змістовності, які закладені художнім уявленням автора. Вступ (Рiano II) занурює нас у спокійні роздуми, у світ тихої, але світлої (мажорний лад) скорботи. Хоральний рух голосів періодично долає зупинку на затриманих акордах, віддзеркалюючи внутрішній стан знесилення. Хід (у партії Piano I) то на малу, то на велику септиму нагадує інтонації 3 Lacrimosa B.A. Моцарта. 3 перших тактів твору

\footnotetext{
11 Ластовецький М. Про генезу та жанрово-тематичні пріоритети творчості Богдани Фільц. Музична украӥністика: сучасний вимір : зб. наук. статей. Київ : ІМФЕ ім. М. Рильського НАН України, 2010. Вип. 5. С. 124. 
діалогічність базується на виконанні по черзі (4 рази) ансамблевих реплік типу «хор - соліст». Подібні до крапель падаючих сліз низхідні вісімки staccato (т. 12) трансформуються у плавне підіймання мелодії у верхній регістр.

Раптовість активізації музичного матеріалу по різних напрямах (динаміка змінюється з $\mathbf{p p}$ на $\mathbf{f}$, темп прискорюється з largo lamentoso на piu mosso) повідомляє слухачів про появу головного об'єкта - літака. Саме постійний рух вісімок угору та вниз, зміна ламаних інтервальних ходів, непропорційність крутих зворотів мелодії, хвилеподібність динаміки - все це з графічною зображальністю імітує вирування літака над аеродромом. Ніби тривожні серцеві удари сприймаються акорди (agitato, sf, Piano II), a пасажі (Piano I) відкривають шлях до безперервного потоку механістичного руху. Цей музично-образний пласт у творі Богдани Фільц співзвучний до ефекту механістичності в деяких темах Дмитра Шостаковича.

Композиторка формує звукозображальну картину польоту за допомогою таких виразових засобів, як: використання ломаних септим і квінт у прийомі ostinato; тембральне згущення у низькому регістрі; ритмоостінатність; спалахи акордових плям; синкоповані опори на секундову інтонацію. Хвилеподібна динаміка створює сонорний пласт, який виконує функцію організації просторового поля твору, у якому учасники двоклавірного дуету можуть відобразити наближення та віддалення звукової хвилі за допомогою управління своїми тілесними рухами (переміщення паралельно розташуванню рук на клавіатурі). Зміна спрямування хроматичних послідовностей передає графіку просторового кружляння літака у різних напрямках.

Лірична присутність автора, що зосереджена у мелодійних мотивах, протиставляється моториці та створює відчуття певної дистанції між творцем і драматичною подією. Особливо це відчувається в епізоді "тепо mosso", де ремарка “dramatico" у поєднанні з "espressivo” вказує на якість кантилени, що потребує від інтерпретаторів драматичнопатетичного піднесення. Плачова семантика посилюється додатковою глибиною відчуттів та супроводжується авторською ремаркою "lacrimoso appassionato", яка належить до сфери «переживання» та «пристрасної музики». Динаміка напруженості після стрімкого набору літаком висоти та в момент його падіння підсилена методом подвійного прискорення (темпового та дольового подрібнення). Зупинка цього піке - «вибух» жахливого акорду, який виконується обома учасниками фортепіанного ансамблю на максимальній динаміці (у кожного fff). Утримання фермати упродовж двох тактів і зависання обертонової звукової хмари створюють справжне відчуття фатальної непоправної катастрофи. 
Розкриття трагічності події, яка відтворена Богданою Фільц у програмній концепції, подано на основі зіставлення зображувального відтворення реальної картини та чуттєвої присутності автора. Концентрація напруги, занурення у сумуючий настрій, неодноразовий перехід від технічно-механістичного рухового елементу до виразномелодійного звучання - все це оформлене у пластично-поліфонічному поєднанні двох фортепіанних партій. 3 одного боку, бачимо риси самостійно-індивідуального характеру кожної інструментальної партії, а 3 іншого боку, драматургія твору вимагає спільного почуття обома виконавцями емоційного тонусу кожної драматургічної частини композиції.

Повернення скорботно-драматичних інтонацій вступу з фразамиламентаціями хоралу (Largo lamentoso) рухається в зворотному (порівняно зі вступом) напрямку, ніби підкреслюючи віддалення нас від реальної події. Як авторська післямова сприймається Coda (Молитва), у якій скорботно-драматичний розвиток одержує своє продовження. Ремарка "religioso" фокусує увагу інтерпретаторів на духовно-релігійній зосередженій інтонації, яка підсумовує драматургічний висновок усього твору, що підтверджено діалогічністю взаємин обох фортепіанних партій. Концентрація всіх духовних сил єднає ансамбль у функціональну цілісність, коли паралельне звучання акордів, які підіймаються до кульмінації, умиротворяє скорботні почуття та стверджує надію.

Система часових координат у творі формується шляхом зіставлення часу події (конкретної ситуації) та часу ліричного (авторської емоційної сповіді). Взаємодія вказаних часових показників відкриває шлях часу філософському (роздуми над подією сучасності у контексті есхатологічних цінностей). Авторський проєкт Богдани Фільц розкривається на рівні музичної драматургії (зіставлення типів часу, контрасту інтонаційного тонусу плачу та жорсткої механічності) та художньої структури (на рівні музичної мови, вербального ряду, цілісної композиції), формуючи яскравий музичний твір з рисами послідовносюжетної і філософсько-драматичної програмності.

Образність "Largo lamentoso" націлена на «опанування тривожного та складного світу, в якому ми живемо, - з трагічною розпеченістю його атмосфери, з його всеохоплюючим техніцизмом» ${ }^{12}$. Вважаємо, що використовуючи ідею гармонійності, притаманну двоклавірному дуету як мікромоделі гармонії соціуму, композиторка вкладає в цей трагічний твір думку про можливість духовного осягнення божественного задуму та сподівань на мудрість людства.

\footnotetext{
12 Зинькевич Е. Гражданственность авторской позиции в контексте музыкальной современности. Проблемы музыкальной культуры : сб. статей. Вып. 1. Київ : Музична Україна. 1997. С. 93. 
3 огляду на власний досвід виконання твору авторами статті, зазначимо, що Богдана Фільц чудово відчуває можливості двоклавірного дуету для відтворення своїх творчих ідей. Вона майстерно застосовує оригінальні фактурні ефекти та технічні прийоми дуетної гри, наприклад, для імітації польоту літака. Разом із тим емоційний складник твору вражає драматизмом та душевним піднесенням і потребує від учасників дуету володіння багатьма навичками (тонкого фразування, спільного дихання, нестандартної педалізації тощо).

Безсумнівно, що "Largo lamentoso" Богдани Фільц - це твір концертного призначення, що здатен будити у слухача найглибші почуття, зберігати історичну пам'ять музичними засобами, виховувати у виконавців вміння реалізовувати в двоклавірному дуеті складну трагедійно-філософську проблематику. Він дає можливість піаністам осягнути велич духовних горизонтів, які можуть відкриватися в поетичному просторі музичного мистецтва.

32020 року весь світ живе під знаком Covid-19. Ніколи ще в історії людства епідемія не призводила до таких катастрофічних наслідків. До липня 2020, коли пишеться ця стаття, за статистикою Всесвітньої Організації Охорони Здоров'я число інфікованих у світі досягло 1300 000, а кількість померлих уже сягає 570 000. Введення глобального карантину паралізувало абсолютно всі сфери людського життя. Але, незважаючи на складні обставини буття, музика продовжує народжуватись та виконувати гуманну катартичну місію. Про це йдеться на сайті Національної музичної академії України ім. П.І. Чайковського: «У час, коли весь світ поклав зусилля для боротьби 3 епідемією коронавірусу, музична підтримка як ніколи важлива для підняття морального духу народів. Твір, який був написаний геніальним композитором Мирославом Скориком під назвою «Я 3 тобою», став символом єдності держав у боротьбі з хворобою» ${ }^{13}$.

Цей актуальний приклад доповнює перелік творів, створених українськими композиторами як рефлексія на трагічні події, та підтверджує думку авторів статті, що музичне мистецтво та митці не залишаються осторонь від проблемних, тяжких питань сьогодення. Навпаки, своєю творчістю вони допомагають подолати кризовий стан людських душ та прагнуть привернути увагу людства до пошуків кращих гармонійних моделей існування, адже «сьогоднішні соціальні катаклізми свідчать лише про одне: корінною, глобальною проблемою людства є проблема розвитку гуманістичної людської свідомості та удосконалювання інструментів керування нею» ${ }^{14}$.

${ }^{13}$ Я $з$ тобою! НMAУ. 13 березня, 2020. Вебсайт. URL: knmau.com.ua>ya-z-toboyu (дата звернення: 08.07.2020).

${ }_{14}$ Самойленко О.І. Психологія мистецтва: сучасні музикознавчі проєкції : монографія. Одеса : Вид. дім «Гельветика», 2020. С. 200. 


\section{ВИСНОВКИ}

Дослідники музичного мистецтва давно знайшли консенсус у питанні, що воно є невід'ємним складником соціокультурного контенту в будьяку історичну епоху. Проведений у статті аналіз доводить, що композитор за допомогою музичної мови здатен оперативно реагувати на проблемні питання часу, фіксувати життєві події та створити музичну картину відчутого і пережитого. Як бачимо, трагічні події часто стають імпульсом для музичних рефлексій, для створення творів, які допомагають подолати страх та сум, очистити людські душі від жахливих наслідків катастрофічних випробувань нашого часу.

Більш ніж 30 творів 17 композиторів 38 країн, до яких звернулись автори статті, безперечно, не вичерпують повністю перелік музики, яка тим чи іншим чином пов'язана з трагічними подіями XX-XXI століть. Усі ці музичні творіння не є абстрактними фантазіями композиторів на теми якихось уявних жахів, навпаки, всі вони просякнуті пам'яттю про страждання та випробування реальних живих людей, кожна краплина сліз яких потребувала катартичного втілення в звуках, мелодіях та гармоніях. Творчі пошуки композиторів різних поколінь та різних національних шкіл перебувають не тільки у руслі поширення конкретної інформації про гострі життєві колізії, але й забезпечують найважливішу функцію поминання, що $\epsilon$ складовою частиною культурної пам'яті людства. Семантика трагічності втілюється у скорботних драматичних музичних інтонаціях та реалізується за допомогою різноманітних складів виконавців - від соліста до симфонічного оркестру та хору.

Проаналізувавши музичні рефлексії європейських та українських композиторів XX-XXI століть на трагічні події нашого часу, можемо зробити висновок, що притаманні музиці комунікативна, зображувальна, виховна, катартична, компенсаторна та інші функції допомагають людині краще зрозуміти себе та своє місце у Всесвіті, адже мистецтво не роз'єднує людей, а дає основу для їх спільного буття та подолання розбіжностей та непорозумінь.

\section{АНОТАЦІЯ}

У статті на основі комплексного підходу досліджується сутність функціонування образів, інспірованих трагічними подіями XX-XXI століть (військовими, техногенними, природними та гуманітарними катастрофами) у творчості європейських та українських композиторів. Виявлено, що ретрансляція смислів наповнює семантику цих творів драматичними та лірико-медитативними інтонаціями. Спостереження за особливостями творчого художнього концепту, чинником якого стали глобальні цивілізаційні колізії, дає змогу авторам статті зробити певні висновки. Важливу роль виконує програмність в інструментальних творах (програма-присвята, програма-концепція, програма-поетичне джерело, 
програма-сюжет, програма-передмова). Для вокально-хорових композицій визначальним складником драматургічного задуму композиторів стає поєднання літургійних, поетичних, документально-інформаційних текстів. У своїх опусах як європейські, так і українські композитори звуковій жорсткості та хаосу протиставляють катартичне, заспокійливе, піднесене звучання мелодійних інтонацій, врівноваженої динаміки та гармонічних знахідок. Музичне трактування змісту трагічних подій 3 позицій громадсько-художнього виміру формується на базі різноманіття жанрового простору (сольні, ансамблеві, оркестрові опуси, вокальносимфонічні полотна). Тематика статті розширює представлення про механізми впливу музичного мистецтва на духовне оновлення людського суспільства, розкриває неповторність драматургічних рішень реалізації суспільно значущих подій у композиторській творчості XX-XXI століть.

\section{ЛІТЕРАТУРА}

1. Гроцкий Д. О творческом методе, политике и Пятой симфонии (беседа Д. Гроцкого с классиком литовской музыки В. Баркаускасом). Ученые записки РАМ им. Гнесиных. 2013. № 1 (4). С. 70-79.

2. Зинькевич Е. Гражданственность авторской позиции в контексте музыкальной современности. Проблемы музыкальной культуры : сб. статей. Вып. 1. Київ : Муз. Україна, 1997. С. 92-102.

3. Зинькевич Е. О настоящем, о былом размышляет Евгений Станкович в беседах с Еленой Зинькевич. Нежин : ЧП Лысенко М.М., 2012. $312 \mathrm{c}$.

4. Ластовецький М. Про генезу та жанрово-тематичні пріоритети творчості Богдани Фільц. Музична украӥністика : сучасний вимір : зб. наук. статей. Київ : ІМФЕ ім. М.Т. Рильського НАН України, 2010. Вип. 5. С. 122-128.

5. Равель в зеркале своих писем / сост. Марсель Жерар и Рене Шалю. Ленинград : Музыка, 1988. 211 с.

6. Розенберг Р. Одесская композиторская школа: к 100-летию основания и к 75-летию Одесской организации НСКУ : монография. Одесса : Астропринт, 2013. 328 с.

7. Самойленко О. Психологія мистецтва: сучасні музикознавчі проєкції : монографія. Одеса : Вид. дім «Гельветика», 2020. 236 с.

8. Элиот Т.С. Традиция и индивидуальный талант. Зарубежная эстетика и теория литературы XIX-XX вв. Трактаты, статьи, эссе. Изд-во Московского университета, 1987. С. 169-176.

9. Я з тобою! НМАУ. 13 березня, 2020. Вебсайт. URL: knmau.com.ua > ya-z-toboyu. (дата звернення: 08.07.2020).

10. Claude Debussy. Correspondance (1882-1918). Gallimard. 2005. $2352 \mathrm{p}$. 


\section{Information about authors: Sherbakova O. K.,}

Candidate of Art Criticism, Associate Professor, Associate Professor at the Department of Chamber Ensemble Odessa National A. V. Nezhdanova Academy of Music 63, Novoselsky str., Odessa, 65023, Ukraine Sherbakov Yu. V., Candidate of Art Criticism, Associate Professor, Associate Professor at the Department of Concertmasters Odessa National A. V. Nezhdanova Academy of Music 63, Novoselsky str., Odessa, 65023, Ukraine 